\title{
SYMPATRIC WINTERING OF RED KITES AND BLACK KITES IN SOUTH-EAST EUROPE
}

\author{
Ivan Literák ${ }^{1}$, David Horal ${ }^{2}$, Rainer RaAB ${ }^{3}$, Hynek Matušík ${ }^{4}$, Stanislav Vyhnal ${ }^{1}$ \\ Dana Rymešová ${ }^{1}$, Péter Spakovszky ${ }^{3}$, Theodora Skartsi ${ }^{5}$, Kostas Poirazidis ${ }^{6}$ \\ Sylvia ZaKKaK ${ }^{7}$, Adrian TomiK ${ }^{8}$ and MyKola SKyrpan ${ }^{9}$ \\ ${ }^{1}$ Department of Biology and Wildlife Diseases, Faculty of Veterinary Hygiene and Ecology \\ University of Veterinary and Pharmaceutical Sciences Brno \\ Palackého tř. 1, 61242 Brno, Czech Republic \\ E-mails: literaki@vfu.cz,https://orcid.org/0000-0001-9885-6840 \\ stanislav.vyhnal@seznam.cz,dana.rymi@post.cz,https://orcid.org/0000-0003-2087-9481 \\ ${ }^{2}$ Nature Conservation Agency of the Czech Republic, Regional Office Brno \\ Kotlářská 51,60200 Brno, Czech Republic, E-mail: david.horal@seznam.cz \\ ${ }^{3}$ Technisches Büro für Biologie Mag. Dr. Rainer Raab, Quadenstrasse 13 \\ 2232 Deutsch-Wagram, Austria, E-mails: rainer.raab@tbraab.at, peter.spakovszky@tbraab.at \\ ${ }^{4} 68713$ Březolupy 324, Czech Republic, E-mail: hynekmb@centrum.cz \\ ${ }^{5}$ WWF Greece, Dadia Program, 21 Lempesi str., 11743 Athens, Greece, E-mail: d.skartsi@wwf.gr \\ ${ }^{6}$ Department of Environmental Sciences, Ionian University \\ Minotou Gianopoulou, Panagoula, 29100, Zakynthos, Greece \\ E-mail: ecopoira@yahoo.gr, https://orcid.org/0000-0003-4239-2041 \\ ${ }^{7}$ Dadia-Lefkimi-Soufli Forest National Park, Management Body, p.o. 1413, 68400 Dadia, Greece \\ E-mail: zak.sylvia@gmail.com, https:/lorcid.org/0000-0002-5229-400X, \\ ${ }^{8}$ Croatian Society for Birds and Nature Protection, I. Meštrovića 74, 31326 Darda, Croatia \\ E-mail: tomikadrian@gmail.com, https://orcid.org/0000-0002-1243-2025, \\ ${ }^{9}$ Ukrainian Birds of Prey Research Centre and West-Ukrainian Ornithological Society \\ Kiyv,Ukraine, E-mail: kolya1992@gmail.com
}

We characterized the spatiotemporal activities in winter grounds of the tagged Red Kites Milvus milvus originated from Austria, Czech Republic and Slovakia and wintering in south-east Europe. Birds arrived to winter grounds in Hungary, Croatia, and Greece from 10 July to 12 December (median 22 October) and departed from winter grounds between 14 February and 22 May (median 14 March), thus staying at winter grounds from 121 to 229 days (median 145, mean $161 \pm 43$ SD). If we regarded kernel density estimate $80 \%$ (area of main foraging and roosting activities) as the best indicator as to the size of home range, we revealed that the size of a home range for Red Kites staying at one place through the entire winter was from 10 to $108 \mathrm{~km}^{2}$ (median 72, mean 60 $36 \mathrm{SD}$ ) and that the size of home range for birds with local shift(s) in winter grounds was from 344 to $620 \mathrm{~km}^{2}$ (median 434, mean $466 \pm 115$ SD). We found not only Red Kites at these places but often also Black Kites Milvus migrans. The numbers of Black Kites wintering together with Red Kites were higher than the number of Red Kites at all Greek winter grounds. At winter grounds in Hungary and Croatia, the number of Black Kites was lower than the number of Red Kites or Black Kites were wholly absent. Sympatric occurrences according to only direct observations of wintering Red and Black Kites were found also in some other locations in Bulgaria, Croatia, Greece and Hungary.

Keywords: raptors, telemetry, winter grounds, home ranges, Milvus milvus, Milvus migrans 


\section{INTRODUCTION}

Red Kite Milvus milvus is essentially a European raptor, and outside Europe, it is found only scattered in North Africa. The total population in the Western Palearctic (and in the world) is between 25,000 and 33,000 breeding pairs. Germany, Switzerland, France, and Spain are the most important areas for its occurrence and are home to about $90 \%$ of the world population (GÉNsBØl \& Thiede 2008, BirdLife International 2015). In 2014, we began using telemetry to study the biology of Red Kite populations in Austria, Czech Republic, and Slovakia exhaustively. These countries are located in the eastern part of the Red Kite breeding area. The density of the Red Kite population is relatively low in Austria, Czech Republic, and Slovakia, consisting respectively only 28-35 breeding pairs (an estimate for 2011-2012), about 165-185 pairs (2012), and 13 pairs (2015) (RAK 2013, BirdLife International 2015, Maderič \& SvetLí́ 2016). From these countries, the Czech Republic provides an excellent example of positive development in a breeding population. Red Kite recolonized the Czech Republic after an absence of about 100 years, with 1974 being the year of the first newly confirmed breeding (ZunA-KRATKY et al. 2000). Since then, the population has expanded to 30-50 breeding pairs in 1985-1989, 70-100 breeding pairs during 2001-2003, and about 175 breeding pairs at present (BirdLife InTERnATIONAL 2004, ŠŤAstný et al. 2006, RAK 2013).

Kites of the nominal subspecies Milvus migrans migrans (BodDAERT, 1783) (hereafter called Black Kites) breed in the Western Palearctic and Central Asia (Ferguson-Lees \& Christie 2001). There exists a relatively small European population (<100,000 pairs), and this declined substantially between 1970 and 1990 (BirdLife International 2004). The birds winter mainly in sub-Saharan Africa, and a few remain to winter in the Mediterranean region, and rather more winter in the Middle East down to southern Arabia (Ferguson-Lees \& Christie 2001). Prior to 2000, the European population of Black Kites was regarded as strictly migratory, even though the northernmost limit of its irregular wintering encompassed southern Spain, France (including Corsica), and Italy, as well as Germany, Switzerland, Greece, Bulgaria, and Romania (GLuTz von Blotzheim et al. 1971, OrtLieb 1998). Exceptionally, wintering Black Kites were observed in the second half of the 20th century also, in Sweden, Poland, and Russia (OrtLieb 1998).

Black Kite is today the most common wintering raptor in Israel, where its numbers have been increasing since the 1980s (SHirihai et al. 2000). They have begun to winter regularly also in Sicily (SARÀ 2003), and significant concentrations of wintering Black Kites have appeared in Turkey (BIRICIK \& KaraKaş 2011). Regular wintering of Black Kites has begun recently in Greece, where dozens of wintering Black Kites of unknown origin constitute quite a new phenomenon in that country (LiтERÁк et al. 2017). Formerly, only a few indi- 
vidually wintering Black Kites had been observed in Bulgaria, but recently (and surprisingly) 7 Black Kites were observed wintering together with 5 Red Kites near the village of Han Asparuhovo in the Upper Thracian Plain (BSPB 2017, Dimitar Demerdzhiev personal information).

Red Kites tagged with telemetry devices (loggers) in Austria, Czech Republic, and Slovakia winter in a broad belt from the Iberian Peninsula to Greece (RAAB et al. 2017). In a part of these birds, we have been able to characterize their spatiotemporal activities at their winter grounds using telemetry data. Moreover, we have been able to check personally local areas chosen by Red Kites in south-east Europe for their wintering and communal roosting and to characterize the habitats they prefer. Surprisingly, we found not only Red Kites at these places but also Black Kites. We also checked some recently known sites in Greece and Bulgaria with many wintering Black Kites and incidentally found Red Kites occurring sympatrically in one of these places in Greece. Sympatric wintering of Red Kites and Black Kites in Greece has been noted recently (LiTERÁK et al. 2017).

This paper aimed to i) identify Red Kite winter grounds in south-east Europe and estimate their home ranges, ii) characterize habitats preferred by Red Kites for wintering in south-east Europe, and iii) characterize an occurrence of Black Kites wintering together with Red Kites in this area. We were able to compare data about sympatrically wintering Red Kites and Black Kites from south-east Europe with such data regarding Red Kites obtained from other European countries and bird populations, including the United Kingdom (Weir 1973, Carter \& Grice 2000), Spain (Heredia et al. 1991, Hiraldo et al. 1993, 1995), Portugal (Ferreira et al. 2014-2015), France (Valet 1975), Germany (Hellmann 1996, Nachtigall et al. 2003, Pfeiffer \& Meyburg 2009), and to compare the data with recent results on this topic presented at the International Red Kite Symposia in 2009 and 2015 (David 2009, De La Puente \& De La Torre 2015). Information about habitat demands of Red Kites originated from Austria, Czech Republic, and Slovakia and wintering in south-east Europe can be useful in protecting this raptor species. Red Kite is regarded as a near-threatened species, and its population is decreasing in various parts of Europe (BirdLIFE INTERNATIONAL 2017).

\section{MATERIAL AND METHODS}

\section{Birds tracked with telemetry devices}

Ten juvenile Red Kites (pulli) equipped with GPS/GSM telemetry loggers on nests in central Europe (Austria, Czech Republic, Slovakia) during 2014-2017 and wintering in south-east Europe were included into the study (Table 1). Saker H loggers (20 g, Ecotone, Poland) were used to track the birds. Loggers were fitted onto the backs of the birds using 
Table 1. Red Kites tagged with telemetry devices which wintered in south-eastern Europe. A, Austria; CZ, Czech Republic; SK, Slovakia; F, female; M, male; red kites D5605 and D5603 are siblings.

\begin{tabular}{lccc}
\hline Red Kite (ring, ringer) & $\begin{array}{c}\text { Origin of bird (country, } \\
\text { nest coordinates) }\end{array}$ & $\begin{array}{c}\text { Date of tagging, } \\
\text { Age of bird }\end{array}$ & Sex \\
\hline CT1587, H. Matušík & CZ, 48.90 N, 17.26 E & 10 Jul 2014, pull. & $\mathrm{F}$ \\
D5605, V. Pečeňák & SK, 48.93 N, 21.75 E & 14 Jun 2015, pull. & $\mathrm{F}$ \\
D5603, V. Pečeňák & SK, 48.93 N, 21.75 E & 14 Jun 2015, pull. & $\mathrm{F}$ \\
JC57514, R. Raab & $\mathrm{A}, 48.55 \mathrm{~N}, 16.77 \mathrm{E}$ & 14 Jun 2015, pull. & $\mathrm{F}$ \\
JC75455, R. Raab & $\mathrm{A}, 48.60 \mathrm{~N}, 16.92 \mathrm{E}$ & 2 Jun 2016, pull. & $\mathrm{F}$ \\
CT1679, H. Matušík & $\mathrm{CZ}, 48.67 \mathrm{~N}, 16.96 \mathrm{E}$ & 5 Jun 2016, pull. & $\mathrm{M}$ \\
CT1682, H. Matušík & $\mathrm{CZ}, 48.62 \mathrm{~N}, 16.95 \mathrm{E}$ & 5 Jun 2016, pull. & $\mathrm{M}$ \\
CT1697, H. Matušík & $\mathrm{CZ}, 48.77 \mathrm{~N}, 16.88 \mathrm{E}$ & 13 Jun 2016, pull. & $\mathrm{M}$ \\
D5607, V. Pečeňák & $\mathrm{SK}, 48.93 \mathrm{~N}, 21.84 \mathrm{E}$ & 15 Jun 2016, pull. & $\mathrm{F}$ \\
D6161, V. Pečeňák & SK, 48.90 N, 21.77 E & 24 Jun 2017, pull. & $\mathrm{F}$ \\
\hline
\end{tabular}

harnesses (backpacks) consisting of $6 \mathrm{~mm}$ Teflon ribbon encircling the body by two loops around the bases of the wings and joined in front of the breastbone. The loggers function in GPS (global position system)/GSM (global system for mobile communication) systems. The GPS positions of the birds were collected according to the individual setting (usually one position fixed per $6 \mathrm{~h}$ ) and were sent as SMS (short message service) text messages by local mobile operators to the Ecotone Center in Poland, where they were saved and archived. Coordinates of bird positions at the winter grounds were analysed using GIS (Geographic Information System) and the software ArcGIS 10.1 with Spatial Analyst and Home Range Tools extensions (Esri, Redlands, USA) and QGIS (A Free and Open Source Geographic Information System, www.qgis.org).

\section{Birds observed}

We checked personally local areas in south-east Europe chosen by Red Kites that we had tagged to observe all Kites, including tagged ones, wintering at these locations and their habitat requirements. We also checked some recently known places in Greece and Bulgaria recognized to be winter grounds for Kites but not for those Red Kites that we had tagged. Moreover, available information on wintering Red and Black Kites from both published (printed and internet), as well as unpublished (personal communication) sources from the countries covered by this study was compiled. In the case of Black Kites, and because we did not follow any satellite-tagged bird, we relied on direct observations of wintering birds only. At Dadia-Lefkimi-Soufli National Park in north-eastern Greece, Black Kites have been counted regularly since 2000 at vulture feeding places on every week. This survey was carried out by WWF Greece during 1987-2015 and by the national park management body since that time. 


\section{Definitions of wintering period, winter grounds}

The wintering period was defined to be the month of January, and the winter grounds were defined as an area where the birds stayed in January. Usually, the birds had arrived to this area before January and left this area after January. Hence, we specified the wintering period as time following autumn migration and preceding spring migration when birds occupied one defined area for the entire wintering period. Periods of autumn and spring migration were characterized by extensive restlessness of each individual accompanied by long-distance movements (hundreds of kilometres) on a continental scale. On the other hand, the wintering period was characterized by the stay of one bird at one place or, less often, at several places not far from one another (separated by dozens of kilometres). Using this method enabled wintering period to be easily stated for birds tracked by telemetry. For other birds observed only visually, wintering period was considered as the period from 1 November through the end of February and winter grounds as whatever place the birds were observed during that time.

\section{SE Europe, characteristics of wintering period and winter grounds}

In the present context, south-east Europe is defined to include Albania, Bosnia and Herzegovina, Bulgaria, Croatia, Greece, Hungary, Kosovo, North Macedonia, Moldova, Montenegro, Romania, Serbia, and Slovenia.

We recorded the following characteristics: location(s) of winter grounds, duration of a tagged Red Kite's stay on winter grounds in days, fidelity of individual Kites to winter grounds, home ranges of individual Red Kites calculated as minimum convex polygon (MCP) 100\%, MCP 95\%, kernel density estimate (KDE) 95\%, KDE 80\%, and KDE 50\%. MCP and KDE (= fixed kernel, href method) were created using Home Range Tools v. 2.0.20 (HRT, http://flash.lakeheadu.ca/ arodgers/hre/) in ArcGIS 10.1. MCP 95\% means the entirety of the winter grounds used, KDE $80 \%$ means foraging and roosting area, and KDE 50\% means core area with main activity concentrated (see Bosch et al. 2010). Habitats of winter grounds and numbers of Red Kites and Black Kites at winter grounds were described during in situ inspection of winter grounds found by tracking tagged Red Kites. Kites on winter grounds were counted mostly at and around their communal roosting places.

All statistical computations were made using Microsoft Excel.

\section{RESULTS}

Wintering in SE Europe of Red Kites tagged with telemetry devices

Red Kites tagged in Austria, Czech Republic, and Slovakia, which wintered in south-east Europe occupied winter grounds in Hungary, Croatia, and Greece (Tables 1-4, Fig. 1). We identified 11 winter grounds with tagged birds. Two Red Kites wintered three times repeatedly at the same winter grounds. One Red Kite changed its winter grounds. Birds arrived to winter grounds between 10 July and 12 December (median 22 October, $\mathrm{n}=15$ cases) and departed from winter grounds from 14 February to 22 May (median 14 March, $n$ 
$=15$ cases), staying at winter grounds from 121 to 229 days (median 145, mean $161 \pm 43 \mathrm{SD}, \mathrm{n}=14$ cases (Fig. 2). An individual found dead 17 days after arrival was excluded from the data set. Distances of winter grounds from the nests of the respective birds ranged from 150 to $1247 \mathrm{~km}$ (median 368, mean 557士399

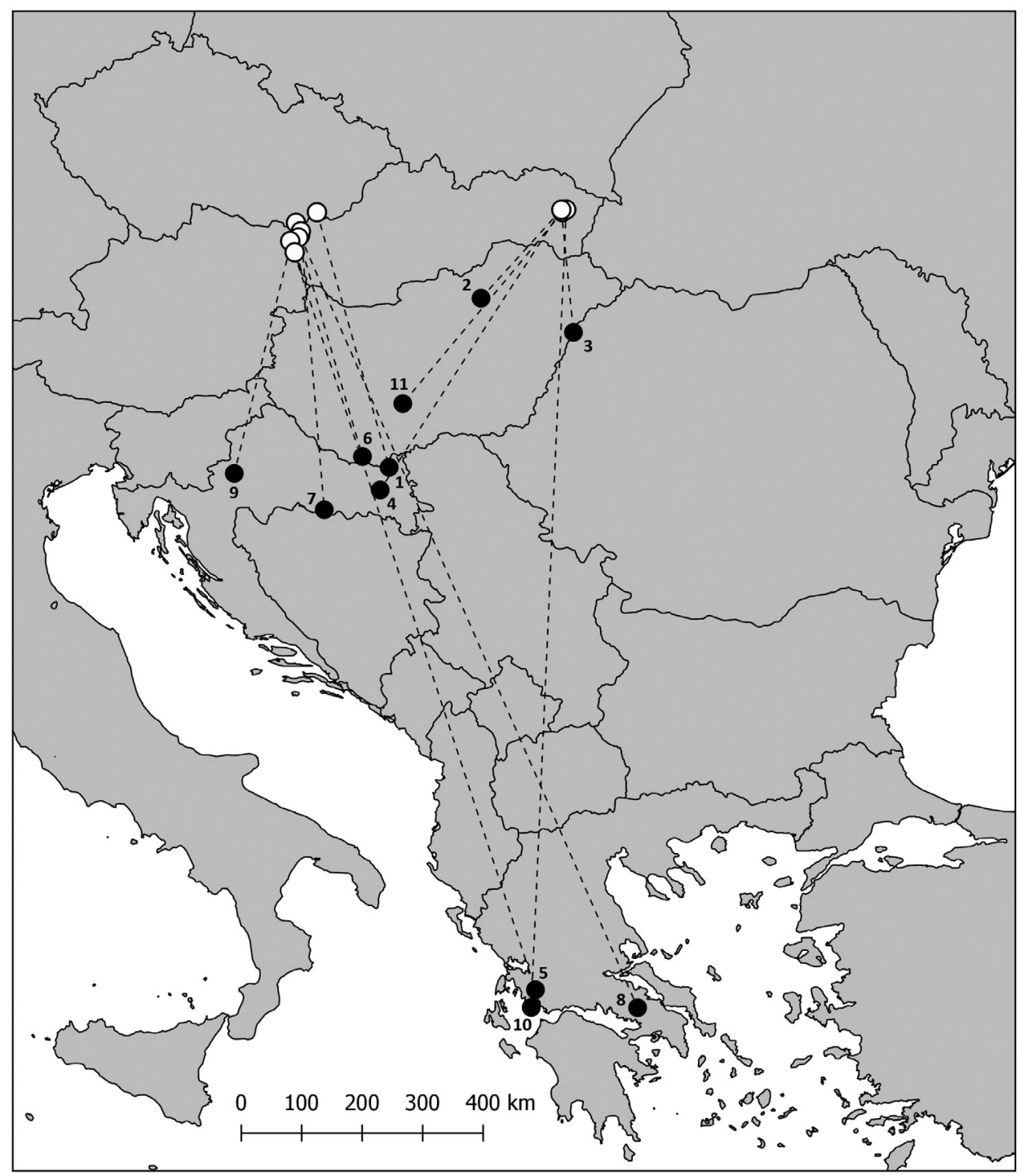

Fig. 1. Locations of winter grounds in SE Europe of Red Kites with telemetry transmitters. White circles indicate nests where Red Kites were tagged. Black circles show winter grounds. Broken lines are links between nests and winter grounds of respective birds (flight course not shown), numbers indicate individual winter grounds. For detail, see Tables 2-4. 


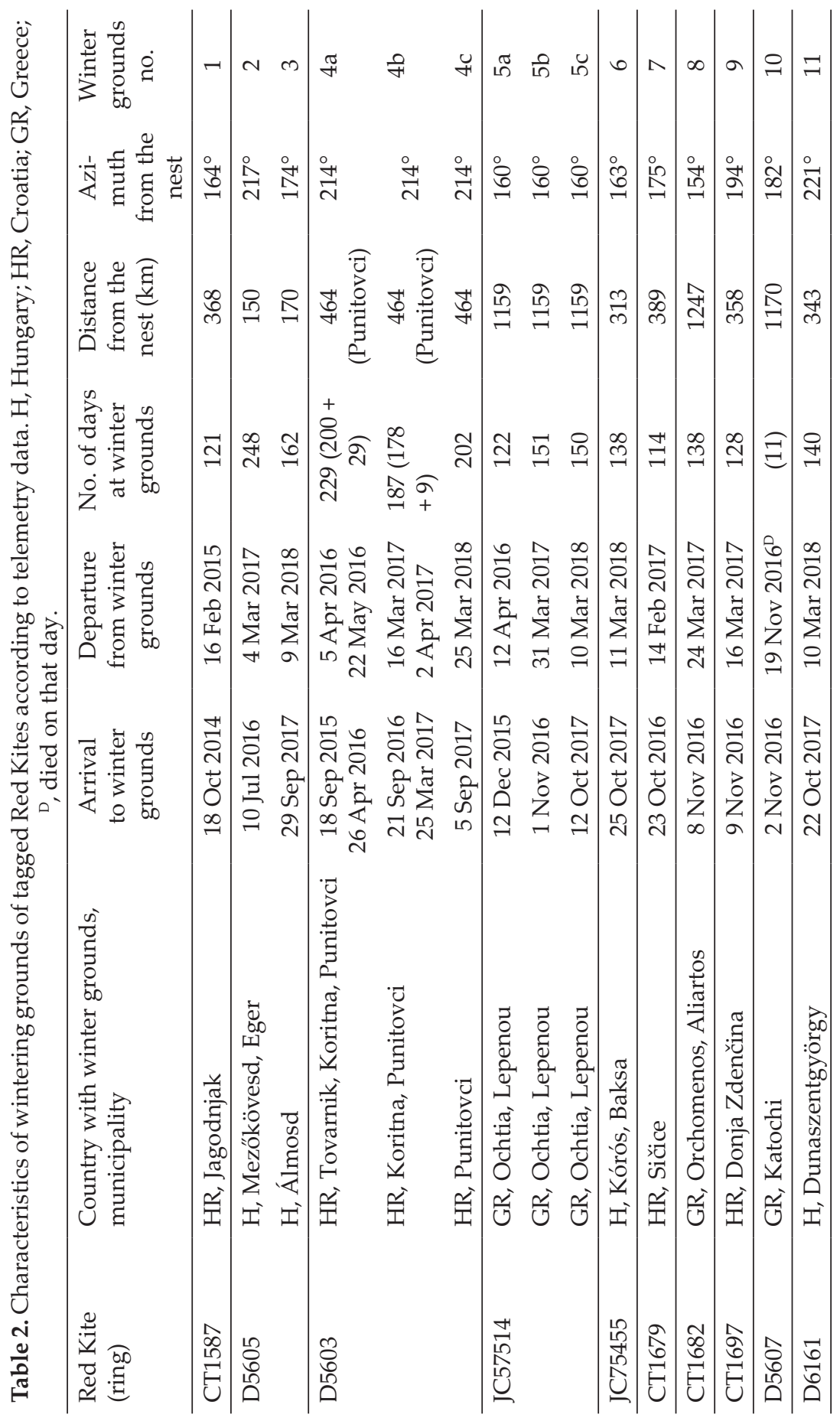


Table 3. Characteristics of winter grounds of tagged Red Kites according to the in situ inspection. All winter grounds were located in lowlands, sometimes at the foot of a hilly forested area or small hills with xerothermic vegetation, usually in agricultural landscape with small fields, meadows, ponds, orchards, small to medium-sized forest patches, domestic animals, and small villages or small cities nearby, from 4 to $150 \mathrm{~m}$ a.s.l.

\begin{tabular}{|c|c|c|c|c|}
\hline $\begin{array}{l}\text { Wintering grounds } \\
\text { no. }\end{array}$ & $\begin{array}{l}\text { Date of } \\
\text { visit }\end{array}$ & $\begin{array}{l}\text { No. of } \\
\text { Red Kites }\end{array}$ & $\begin{array}{l}\text { No. of } \\
\text { Black } \\
\text { Kites }\end{array}$ & Observer \\
\hline \multirow[t]{3}{*}{1 (Jagodnjak) } & 26.03.2015 & 7 & 1 & I. Literák, H. Matušík, L. Peške \\
\hline & 22.01.2017 & 8 & - & I. Literák, H. Matušík \\
\hline & 8.01.2018 & 4 & - & A. Tomik \\
\hline 2 (Eger) & 29.10 .2016 & 1 & - & M. Horváth \\
\hline 3 (Álmosd) & 17.10.2017 & 1 & - & S. Konyhás, M. Dudás, G. Papp \\
\hline 4a (Punitovci) & 21.01.2016 & 11 & - & $\begin{array}{l}\text { I. Literák, H. Matušík, R. } \\
\text { Petro }\end{array}$ \\
\hline 4b (Punitovci) & 23.01.2017 & 2 & - & I. Literák, H. Matušík \\
\hline \multirow[t]{4}{*}{ 4c (Punitovci) } & 27.10.2017 & 13 & 3 & D. Laczik \\
\hline & 26.12.2017 & 3 & 6 & J. Ledinšćak \\
\hline & 5.01 .2018 & 4 & 8 & J. Ledinšćak, A. Tomik, \\
\hline & 10.02.2018 & 7 & 10 & $\begin{array}{l}\text { D. Horal, I. Literák, M. } \\
\text { Literáková }\end{array}$ \\
\hline \multirow[t]{2}{*}{ 5a (Ochtia, Lepenou) } & 23.01.2016 & 5 & 65 & I. Literák, H. Matušík, R. Petro \\
\hline & 28.02.2016 & 6 & 56 & E. Shogolev \\
\hline \multirow[t]{4}{*}{ 5b (Ochtia, Lepenou) } & 15.01.2017 & 12 & 61 & N. Probonas \\
\hline & 30.01 .2017 & 6 & 68 & I. Literák, H. Matušík \\
\hline & 5.03 .2017 & $\min .1$ & 67 & R. Raab, B. Raab \\
\hline & 31.03.2017 & $\min .1$ & 65 & R. Raab, B. Raab \\
\hline \multirow[t]{9}{*}{6 (Baksa) } & 9.10 .2017 & 31 & 1 or 2 & D. Laczik \\
\hline & 15.10 .2017 & 24 & 2 & D. Laczik \\
\hline & 21.10.2017 & 32 & 2 & D. Laczik, T. Budai \\
\hline & 23.10.2017 & 32 & 2 & D. Laczik \\
\hline & 26.10 .2017 & 35 & 0 & D. Laczik, T. Budai \\
\hline & 2.01 .2018 & unknown & 2 & Á. Takács \\
\hline & 6.01 .2018 & 37 & 2 & D. Laczik \\
\hline & $\begin{array}{l}\text { 12.-14.01. } \\
2018\end{array}$ & 37 & 2 & Z. Meisztericz, Á. Takacs \\
\hline & 2.02 .2018 & 47 & 4 & L. Németh-Bóka \\
\hline 7 (Sičice) & 24.01.2017 & 3 & - & I. Literák, H. Matušík \\
\hline
\end{tabular}


Table 3 (continued)

\begin{tabular}{llccl}
\hline $\begin{array}{l}\text { Wintering grounds } \\
\text { no. }\end{array}$ & $\begin{array}{l}\text { Date of } \\
\text { visit }\end{array}$ & $\begin{array}{c}\text { No. of } \\
\text { Red Kites }\end{array}$ & $\begin{array}{l}\text { No. of } \\
\text { Black } \\
\text { Kites }\end{array}$ & Observer \\
\hline 8 (Aliartos) & 2.02 .2017 & 5 & 6 & I. Literák, H. Matušík \\
9 (Donja Zdenčina) & 25.01 .2017 & 3 & - & I. Literák, H. Matušík \\
10 (Katochi) & 31.01 .2017 & - & - & I. Literák, H. Matušík \\
11 (Dunaszentgyörgy) & 16.10 .2017 & 4 or 5 & - & M. Gubacsi \\
& 20.10 .2017 & 2 & - & M. Gubacsi \\
& 21.10 .2017 & 3 & - & M. Gubacsi \\
& 23.10 .2017 & 3 & - & D. Laczik \\
& 26.10 .2017 & 5 & - & M. Gubacsi \\
\hline
\end{tabular}

$\mathrm{SD}, \mathrm{n}=11$ cases from 10 individuals, individuals repeatedly wintering at the same site were included into the calculation only once), and azimuths ranged from $106^{\circ}$ to $221^{\circ}$ (median 175 , mean $183 \pm 23 \mathrm{SD}, \mathrm{n}=11$ cases).

Table 4. Home ranges of individual Red Kites wintering in south-eastern Europe (MCP 95, whole area used; KDE 80, foraging and roosting area; KDE 50, core area with main concentrated activity, see Bosch et al. 2010; ${ }^{\text {LSWG }}$, important local shift in winter grounds).

\begin{tabular}{lcccccc}
\hline $\begin{array}{l}\text { Red kite (ring), } \\
\text { winter grounds no. }\end{array}$ & $\begin{array}{c}\text { No. of } \\
\text { fixes }\end{array}$ & $\begin{array}{c}\text { MCP 100 } \\
\mathrm{km}^{2}\end{array}$ & $\begin{array}{c}\mathrm{MCP} \text { 95 } \\
\mathrm{km}^{2}\end{array}$ & $\begin{array}{c}\text { KDE 95 } \\
\mathrm{km}^{2}\end{array}$ & $\begin{array}{c}\text { KDE 80 } \\
\mathrm{km}^{2}\end{array}$ & $\begin{array}{c}\text { KDE 50 } \\
\mathrm{km}^{2}\end{array}$ \\
\hline CT1587, 1 & 812 & 483 & 84 & 88 & 23 & 7 \\
D5605, 2 LSWG & 960 & 1607 & 661 & 668 & 344 & 11 \\
D5605, 3b & 522 & 88 & 39 & 45 & 18 & 5 \\
D5603, 4a LSWG & 1824 & 2478 & 2284 & 1268 & 620 & 230 \\
D5603, 4b & 734 & 467 & 193 & 216 & 91 & 26 \\
D5603, 4c & 823 & 307 & 195 & 188 & 73 & 13 \\
JC57514, 5a & 632 & 190 & 165 & 208 & 108 & 36 \\
JC57514, 5b & 872 & 133 & 108 & 150 & 76 & 21 \\
JC57514, 5c & 672 & 146 & 123 & 217 & 108 & 43 \\
JC75455, 6 & 956 & 680 & 162 & 173 & 70 & 26 \\
CT1679, 7 & 613 & 49 & 24 & 21 & 10 & 4 \\
CT1682, 8 8 LSWG & 678 & 636 & 456 & 975 & 434 & 169 \\
CT1697, 9 & 811 & 326 & 23 & 39 & 15 & 6 \\
D5607, 10 & 136 & 431 & 272 & 238 & 94 & 35 \\
D6161, 11 & 889 & 175 & 79 & 82 & 30 & 7 \\
\hline
\end{tabular}


Table 5. Unpublished data or data from electronic databases about observations of sympatric occurrence of Red Kites and Black Kites in south-eastern Europe in winter (November-February) from 1998 to winter 2017/2018. Abbreviations: H, Hungary; HR, Croatia; GR, Greece. Data sources: personal communications; Archives of Croatian Society for Birds and Nature Protection; personal databases from Szilárd Dároczi, László Haraszthy, Roy Clarke, and Dimitris Vasilakis; internet databases: www.observation.org, www.bspb.org, www.eBird.org, www.birding.hu, www.rombird.ro, www.milvus.ro

\begin{tabular}{|c|c|c|c|c|}
\hline Country; location, region & Date & $\begin{array}{c}\text { No. of } \\
\text { Red Kites }\end{array}$ & $\begin{array}{l}\text { No. of } \\
\text { Black } \\
\text { Kites }\end{array}$ & Observer \\
\hline GR; Evros Delta, Thrace & early Jan 2000 & $2-3$ & 20 & G. Gradev \\
\hline H; Pécs, Baranya & 20 Jan 2018 & 1 & 2 & G. Molnár \\
\hline $\begin{array}{l}\text { HR; Darda-Lug-Grabovac } \\
\text { fields, Osijek-Baranja }\end{array}$ & 31 Jan 2007 & 2 & 1 & A. Tomik \\
\hline $\begin{array}{l}\text { HR; Darda-Lug-Grabovac } \\
\text { fields, Osijek-Baranja }\end{array}$ & 23 Jan 2008 & 2 & 1 & $\begin{array}{l}\text { T. Mikuska } \\
\text { H. Kuttler }\end{array}$ \\
\hline $\begin{array}{l}\text { HR; Kneževo fields, Osijek- } \\
\text { Baranja }\end{array}$ & 16 Jan 2015 & 2 & 1 & $\begin{array}{l}\text { T. Mikuska } \\
\text { A. Tomik }\end{array}$ \\
\hline
\end{tabular}

Usually, we found during in situ inspections of winter grounds a number of Red Kites wintering together at winter grounds revealed by tracking

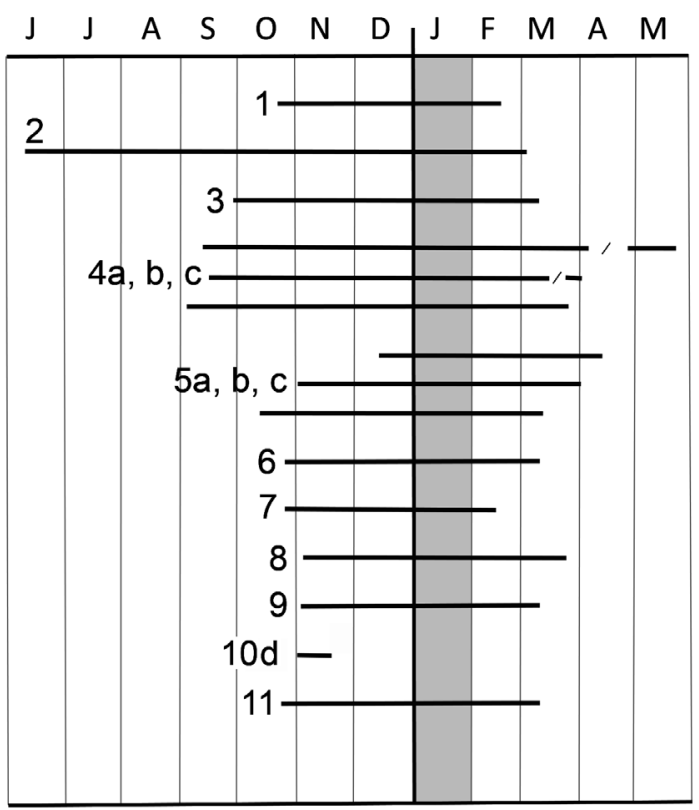

Fig. 2. Lengths of stay for individual Red Kites at winter grounds (for details, see Tables 2-4) of tagged Red Kites, but some of the tagged Red Kites wintered alone (Table 3). We also found Black Kites wintering together with Red Kites at the same winter grounds in 6 out of 14 cases (Table 3). The numbers of Black Kites wintering together with Red Kites were higher than the number of Red Kites in all Greek winter grounds. At winter grounds in Hungary and Croatia, the number of Black Kites was lower than the number of Red Kites or Black Kites were entirely absent. Habitats of all winter grounds were similar: They were located in lowlands with an agricultural landscape characterized by small fields, orchards and meadows, and small 
Table 6. Sympatric occurrence of Red Kites and Black Kites wintering in Dadia National Park in north-eastern Greece during 1998-2019.

\begin{tabular}{lcccl}
\hline Month & Year & $\begin{array}{c}\text { No. of Red } \\
\text { Kite }\end{array}$ & $\begin{array}{c}\text { No. of Black } \\
\text { Kite }\end{array}$ & Source \\
\hline Nov & 2012 & 2 & 19 & WWF Greece unpubl. \\
Dec & 2012 & 1 & 16 & WWF Greece unpubl. \\
Feb & 2018 & $2(1 \mathrm{ad}, 1$ juv $)$ & $50-60$ & I. Literák, D. Horal, L. Sidiropoulos \\
Jan & 2019 & $3(2 \mathrm{ad}, 1$ juv $)$ & 62 & I. Literák, M. Skyrpan \\
\hline
\end{tabular}

to medium-sized forest patches from 4 to $150 \mathrm{~m}$ a.s.l. (median 90 , mean $87 \pm 39$ $\mathrm{SD}, \mathrm{n}=11$ cases). Small villages to medium-sized cities were nearby Kite winter grounds (Table 3 ).

Two space utilization strategies were identified in wintering Red Kites: 1) birds staying at a single place for the whole winter with smaller winter home ranges, and 2) birds locally shifting their original positions over distances of several dozen kilometres and thus larger winter home ranges (Table 4). If we assume KDE $80 \%$ (area of main foraging and roosting activities) to be the most important marker of home range size, then we found that the size of a home range of birds staying at one place for the whole winter was from 10 to $108 \mathrm{~km}^{2}$ (median 72 , mean $60 \pm 36 \mathrm{SD}, \mathrm{n}=12$ cases), whereas the home range size of birds with local shift(s) within winter grounds ranged from 344 to 620 $\mathrm{km}^{2}$ (median 434, mean $466 \pm 115 \mathrm{SD}, \mathrm{n}=3$ cases) (Fig. 3).

Wintering of Red Kites and Black Kites in SE Europe according to direct field observations

A number of winter observations (from Albania, Bulgaria, Greece, Hungary, Croatia, and Romania) which were unpublished or published only in various ornithological electronic databases were checked. Only one species of Kites was observed in most of the individual observations. Few cases of sympatric occurrences of Red Kites and Black Kites are shown in Table 5. Sympatric occurrence of both Kite species was noted in the Hungarian/Croatian border region Baranya/Baranja, as well as in the Evros Delta area of north-eastern Greece and (roughly 50 km distant) in Greece's Dadia-Soufli-Lefkimi National Park (Table 5 and Table 6). All observations from the locations revealed by the occurrence of satellite-tagged birds are included in Table 3, not in Table 5. 


\section{DISCUSSION}

Red Kite winter grounds in SE Europe

Formerly, only a little information was available about wintering of Kites in south-east Europe, and nearly nothing was known about the origins of birds wintering in this area. According to the results from bird ringing, a

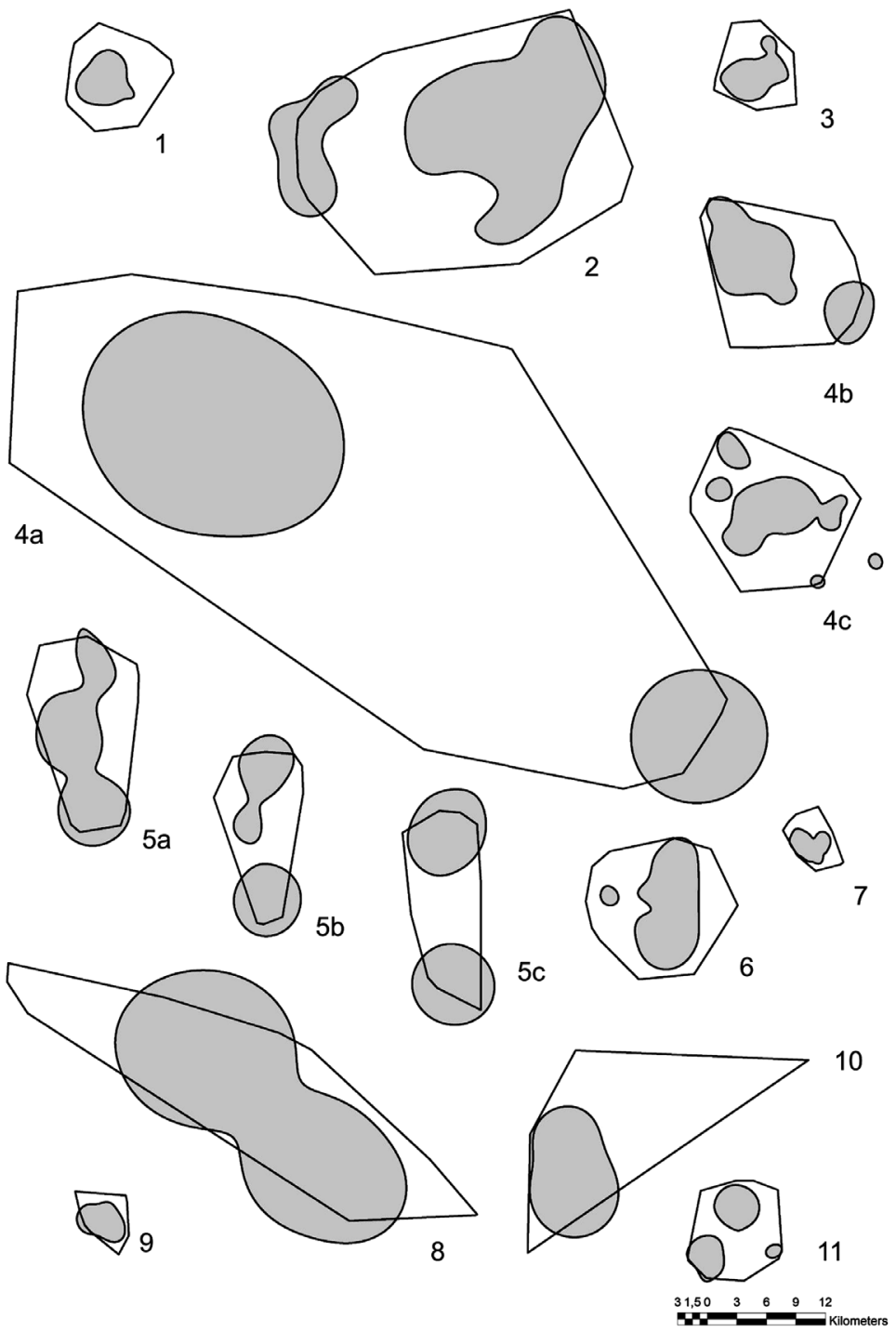

Fig. 3. Home ranges as minimum convex polygon $95 \%$ (empty polygons) and core areas as kernel density estimates 50\% (in grey) of Red Kites in SE Europe (for details, see Tables 2-4) 
Red Kite wintering near Edessa, northern Greece and found freshly dead on 2 February 1989 had been ringed as pullus in north-eastern Slovakia on 16 June 1984 (the distance between these places was 911 km) (SCHröpfer 2008, Jaroslav Cepák, Bird Ringing Center of the National Museum in Prague, Czech Republic, ID Z3671632).

According to our results, in south-east Europe, Red Kites arrived to winter grounds, usually in October, and they departed from winter grounds usually, in March, staying at winter grounds for an average of 161 days. In Portugal, they arrive to winter grounds at the end of September and depart between February and the beginning of April (CARTHY et al. 2010). In Spain, Red Kites arrived to winter grounds between 3 October and 15 December and departed from February to April (Pfeiffer \& Meyburg 2009, Aebischer 2009, Vidal-Mateo et al. 2015).

Red Kites followed for more than one winter in Spain showed winter grounds site fidelity (Pfeiffer \& Meyburg 2009, Vidal-Mateo et al. 2015). In our study, winter site fidelity was well documented in three successive years by 2 Red Kites in south-east Europe: D5605 at Greek Ochtia/Lepenou and D5603 at Croatian Punitovci. Red Kites with fidelity to winter grounds usually arrived at and departed earlier from the same winter grounds. This pattern of behaviour was also observed in a Lesser Black-backed Gull (Larus fuscus intermedius) tracked for six wintering periods. Its arrivals and departures from the wintering area on the Algerian coast occurred progressively earlier, from early December to early November and from late May to late March, respectively (PüTz et al. 2008).

Usually, Red Kites wintering in Southeast Europe occupied winter grounds areas of about $60 \mathrm{~km}^{2}(\mathrm{KDE} 80 \%)$. Sometimes, they moved in winter, and hence, their home ranges were larger (in these cases, average home range measured as KDE $80 \%$ was $466 \mathrm{~km}^{2}$ ). These values were substantially higher than those of home ranges from other areas (i.e. UK, Germany, and Spain) where wintered Red Kites were studied formerly, but the results were based on less precise methods of direct observations (WEIR 1973), radio-tracking and sightings of wing-tagged individuals (Heredia et al. 1991, Hiraldo et al. 1993, 1995, Hellmann 1996, Carter \& Grice 2000, Nachtigall et al. 2003).

Red Kite is a highly social species in winter when large numbers gather every evening at communal roost sites, often remaining faithful to the same site for many years (Heredia et al. 1991, Carter \& Grice 2000, Aebischer 2009, Ferreira et al. 2014-2015, De Rosa 2015). It seems that usually smaller groups of Red Kites winter in south-east Europe compared to what is seen at winter grounds on the Iberian Peninsula, Switzerland and Italy (Heredia et al. 1991, Aebischer 2009, Ferreira et al. 2014-2015, De Rosa 2015).

Wintering Red Kites using roost sites feed more often on prey prelocated by others, although lone roosters also forage and discover food alone. After 
finding food, Red Kites tend to shift to a new roost site and foraging area $\left(\mathrm{HI}^{-}\right.$ RALDO et al. 1993). This could explain why some Red Kites wintering within some areas in south-east Europe shifted their winter grounds and substantially enlarged their home ranges during the winter season (cases of D5605 in 2016/2017, D5603 in 2015/2016 and 2016/2017, and CT1682 in 2016/2017). In south-east Europe, Kites choose for wintering locations in lowlands. These are usually agricultural landscapes with small fields and meadows, small to medium-sized forest patches, and small villages around. Red Kites wintering in Spain occupied an extensive agricultural landscape with cowherds, small fields, and occasionally, a rubbish dump was used for foraging (PFEIfFer \& Meyburg 2009).

\section{Sympatric occurrence of wintering Red Kites and Black Kites in SE Europe}

Based on telemetry tracking of Red Kites tagged in Austria, Czech Republic and Slovakia, we were able to reveal winter grounds of Red Kites in south-east Europe, which were occupied often and used sympatrically by Black Kites. Other sympatric winter grounds of these Kites were revealed by direct observations independent of telemetry tracking.

In south-east Europe, it seems that Greece is the most important country for sympatric wintering of Red Kites and Black Kites. Croatia, Hungary, and Bulgaria are also important countries from this point of view (see also LiTERÁK et al. 2017, BSPB 2017).

In Greece, there have been fewer than 40 Red Kite records since the mid19th century. These have been mostly in winter from November to March (Handrinos \& AKRiotis 1997). In February 2004 and February 2009, respectively, 1 and 1 Red Kite were observed on the Evros Delta (Mills 2011). In winter, Black Kites were rare but local in Greece (МакATsch 1948, Handrinos \& АкRготіs 1997). The newly observed dozens of Black Kites wintering in Greece constitute a new phenomenon (LiteráK et al. 2017). Sympatric wintering of Red Kites and Black Kites was found in Ochtia/Lepenou area during 2015/2016 and repeatedly confirmed in 2016/2017 (LiteRÁK et al. 2017). It seems that sympatric wintering of Red Kites and Black Kites in Greece near the Turkish border (the Evros Delta and Dadia-Lefkimi-Soufli National Parks) is also relatively new and supposedly first registered in early January 2000, when about 20 Black Kites and at least 2 Red Kites were observed in the Evros Delta. Sympatric occurrence of about 30 Black Kites and 2 Red Kites ( 1 juvenile and 1 adult) at the artificial feeding place for vultures near Dadia were also observed in early February 2018, and quite recently, on 30 January 2019, 2 adult and 1 juvenile Red Kites have been observed among 62 Black Kites at the feeding place in Dadia (for details, see Tables 5 and 6). 
Red Kites rarely nested in the north-eastern part of Croatia (Croatian Baranja) until the 1960s (BARIšIć 2013). Wintering of Red Kites in Croatian Baranja was noted from the year 2002 (BARIšIć 2013). Recently, 7 Red Kites were observed in Jagodnjak in Croatian Baranja during 26-27 January 2015, together with 1 Black Kite (LiterÁк et al. 2017). Eight wintering Red Kites were observed at the same place in Jagodnjak on 22 January 2017. In Punitovci, location in Croatian East Slavonia, 11 and 2 wintering Red Kites were observed on 21 January 2016 and on 23 January 2017, respectively (for details, see Table 3). Although Black Kites are rarely seen wintering guests in both Croatia and Hungary, they nevertheless have relatively often been observed together with Red Kites. Moreover, surprisingly, 1 Black-eared Kite (Milvus milvus lineatus) was observed in Jakuševac near Zagreb, Croatia, on 18 February 2012 (KRALJ \& BARIšIĆ 2013).

It now seems that Red Kites do not breed in Bulgaria (BIRDLife INTERNATIONAL 2004, 2015) or that its breeding is extremely rare and not extending beyond 1 breeding pair (Iankov 2007, David 2009, Golemanski 2011). Red Kites wintering in Bulgaria are also rare (STOYNov et al. 2014). Some Black Kites have, in the past, stayed to overwinter in Bulgaria (Patev 1950, Kumerlove 1956, Baumgart 1971, Simeonov et al. 1990). Golemanski (2011), nevertheless define Black Kite as a breeding summer visitor, passage migrant, and partly winter visitor because the number of winter records increased after 2000. Seven Black Kites sympatric along with 5 Red Kites were observed in Bulgaria during January 2015 in the Upper Thracian Plain (BSBP 1917). Bulgaria could become an important place for wintering Kites in the near future, similarly as Croatia and Greece became important from that point of view quite recently. This idea can also be supported by the finding of a new Black Kite communal roost site near a garbage dump at Shishmantsi close to the city of Plovdiv in February 2018, with 8-11 roosting birds (I. LiteráK and D. HoRAL, personal observation) and by the fact that next winter, 16 Black Kites sympatric along with 1 Red Kite were observed in Manole between Shishmantsi and Plovdiv on 23 January 2019 (I. LiterÁk and M. SKYRPAN, personal observation).

It seems the breeding population of Red Kites is increasing in some areas on the eastern edge of its breeding distribution (the Czech Republic, for example, see RAK 2013). Hence the number of Red Kite's wintering and communally roosting in south-east Europe (the eastern edge of Red Kite's winter distribution today) is increasing, too. Communal roosts of Red Kites in Southeast Europe can be a base for newly appearing sympatric roosting of Black Kites wintering in some parts of Southeast Europe (Greece, for example, see LiterÁK et al. 2017). The opposite may also be true, as a higher concentration of commonly wintering (roosting) Black Kites in south-east Europe can attract Red Kites for sympatric wintering. 
Acknowledgements - We would like to thank H. Alivizatos (GR), V. Arkumarev (BG), T. Bino (AL), A. Chalivelentzios (GR), R. Clarke (UK/GR), Sz. Dároczi (RO), S. Delipouliou (GR), D. Demerdzhiev (BG), V. \& D. Dobrev (BG), M. Dudás (H), G. Gradev (BG), M. Gubacsi $(\mathrm{H})$, L. Haraszthy $(\mathrm{H})$, M. Horváth $(\mathrm{H})$, P. Iankov (BG), G. Iliadis (GR), S. Konyhás $(\mathrm{H})$, J. Kralj (HR), D. Laczik (H), J. Ledinšćak (HR), M. Literáková (CZ), B. Maderič (SK), Z. Meiszterics (H), Š. Mikiara (SK), L. Németh-Bóka (H), G. Papp (H), V. Pečeňák (SK), L. Peške (CZ), R. Petro (CZ), L. Profirov (BG), N. Probonas (GR), B. Raab (A), E. Shogolev (UA/GR), L. Sidiropoulos (GR), S. Stoychev (BG), K. Tsiandikoudis (GR), I. Tziambazis (GR) and D. Vasilakis (GR), who helpfully cooperated with us in this study. The study was supported by the project FVHE/Literák/ITA2019 from the University of Veterinary and Pharmaceutical Sciences, Brno, Czech Republic

\section{REFERENCES}

Aebischer, A. (2009): Migration and wintering of Swiss Red Kites assessed by satellite telemetry. Pp. 48-51. In: David, F. (ed.): Proceedings of the Red Kite International Symposium, October 17-18, 2009, Montbéliard, France. - LP Mission Rapaces and LPO FrancheComté, Paris.

BARIšić, S. (2013): Crvena lunja Red Kite Milvus milvus Linnaeus, 1758. Pp. 75-76. In: Tutiš, V., Kralj, J., Radović, D., Ćiković, D. \& Barišić S. (eds): Crvena Knjiga Ptica Hrvatske, Red Data Book of Birds of Croatia. - Ministarstvo zaštite okoliša i prirode, Državni zavod za zaštitu prirode, Republika Hrvatska, Zagreb.

Baumgart, W. (1971): Beitrag zur Kenntnis der Greifvögel Bulgariens. - Beiträge zur Vogelkunde 17: 33-70.

BiriciK, M. \& KaraKaş, R. (2011): Black Kites (Milvus migrans) winter in Southeastern Anatolia, Turkey. - Journal of Raptor Research 45: 370-373. https://doi.org/10.3356/JRR10-109.1

BirdLife International (2004): Birds in Europe: Population estimates, trends and conservation status. BirdLife Conservation Series No. 12. - BirdLife International, Cambridge, 172 pp.

BirdLife InTERnATIONAL (2015): European Red List of Birds. The IUCN red list of threatened species. - Office for Official Publications of the European Communities, Luxembourg, 75 pp.

BirdLife International (2017): Milvus milvus (amended version of 2016 assessment). The IUCN Red List of Threatened Species 2017: e.T22695072A110921280. https://doi. org/10.2305/IUCN.UK.2017-1.RLTS.T22695072A110921280.en

Bosch, R., Real, J., Tintó, A., Zozaya, E. L. \& Castell, C. (2010): Home-range and patterns of spatial use in territorial Bonelli's Eagles Aquila fasciata. - Ibis 152: 105-117. https:// doi.org/10.1111/j.1474-919X.2009.00985.x

BSPB (Bulgarian Society for the Protection of Birds) (2017): New temporary settlement area of Imperial Eagles and other rare species discovered. [In Bulgarian] http://bspb.org/ bg/news/Otkrito-novo-miasto-za-vremenno-prebivavane-na-tsarski-orli-i-drugiredki-vidove.html

Carter, I. \& Grice, P. (2000): Studies of re-established Red Kites in England. - British Birds 93: 304-322.

Cartry, P., Costa, H., Elias, G. \& Matias, R. (2010): Aves de Portugal. Ornitologia do território continental [Birds of Portugal - the Ornithology of the continental territory]. - Assírio and Alvim, Lisboa, Portugal, 944 pp. [in Portuguese] 
David, F. (ed.) (2009): Proceedings of the Red Kite International Symposium, October 17-18, 2009, Montbéliard, France. - LPO Mission Rapaces and LPO Franche-Comté, Paris, 164 pp.

De La Puente, J. \& De La Torre, V. (eds) (2015): Abstracts Book of the II International Symposium on the Red Kite. - Binaced (Huesca), Spain, Edit Grupo Ornitológico SEO-Monticola and Fondo de Amigos del Buitre, $81 \mathrm{pp}$.

De Rosa, D., De Lisiop, L., Loy, A., Senese, A., Bucci, C. \& Ceccolini, G. (2015): Red Kite in Molise: Monitoring of roosts and estimates of breeding population. Pp. 58-59. In: De La Puente, J. \& De La Torre, V. (eds): Abstracts Book of the II International Symposium on the Red Kite. - Binaced (Huesca), Spain, Edit Grupo Ornitológico SEO-Monticola and Fondo de Amigos del Buitre.

Ferguson-Lees, J., Christie, D. A. (2001): Raptors of the World. Helm Identification Guides. - Christopher Helm, London, 992 pp.

Ferreira, R., Zina, H., Marques, A. T., Delgado, A., Venade, D. \& Costa, H. (2014-2015): Wintering population of Red Kite Milvus milvus in the Castro Verde SPA (Portugal). - Airo 23: 55-60.

Génsbol, B. \& Thiede, W. (2008): Collins Birds of Prey. - HarperCollins Publishers, London, $416 \mathrm{pp}$.

Glutz von Blotzheim, U. N., Bauer, K. \& Bezzel, E. (1971): Handbuch der Vögel Mitteleuropas. Bd: 4: Falconiformes. - Akademische Verlagsgesellschaft, Wiesbaden, 943 pp.

Golemanski, V. (ed.) (2011): Red data book of the Republic of Bulgaria. Volume 2. Animals. IBEI - BAS \& MOEW, Sofia, 383 pp.

Handrinos, G. \& Akriotis, T. (1997): The birds of Greece. - Christopher Helm, London, 336 pp.

Hellmann, M. (1996): Untersuchungen an Schlafplätzen von Rotmilan und Schwarzmilan (Milvus milvus, M. migrans) im nördlichen Harzvorland. - Ornitologische Jahresberichte des Museum Heineanum 14: 111-132.

Heredia, B., Alonso, J. C., Hiraldo, F. (1991): Space and habitat use by Red Kites Milvus milvus during winter in the Guadalquivir marshes: a comparison between resident and wintering populations. - Ibis 133: 374-381. https://doi.org/10.1111/j.1474919X.1991.tb04585.x

Hiraldo, F., Heredia, B. \& Alonso, J. C. (1993): Communal roosting of wintering Red Kites Milvus milvus (Aves, Accipitridae): Social feeding strategies for the exploitation of food resources. - Ethology 93: 117-124. https://doi.org/10.1111/j.1439-0310.1993.tb00983.x

Hiraldo, F., Bustamante, J., Viñuela, J. (1995): Überwinterung des Rotmilans (Milvus milvus) in Spanien. - Zeitschrift für Vogelkunde und Naturschutz in Hessen, Vogel und Umwelt, Sonderheft, pp. 53-58.

IAnkov, P. (ed.) (2007): Atlas of breeding birds in Bulgaria. Conservation Series, Book 10. Bulgarian Society for the Protection of Birds, Sofia, 680 pp.

Kralj, J. \& BARIšić, S. (2013): Rare birds in Croatia. Third report of the Croatian Rarities Committee. - Natura Croatica 22: 375-396.

Kumerloeve, H. (1956): Der Schwarzmilan als Wintergast in Bulgarien. - Vogelwelt 77: 2.

Literák, I., Horal, D., Alivizatos, H. \& Matušík, H. (2017): Common wintering of Black Kites (Milvus migrans migrans) in Greece, and new data on their wintering elsewhere in Europe. - Slovak Raptor Journal 11: 91-102. https://doi.org/10.1515/srj-2017-0001

MAderič, B. \& SvetLí́ J. (2016): Správy pracovných skupín za rok 2015: Haja červená (Milvus milvus) [Reports of working groups 2014: Red Kite (Milvus milvus)]. Birds of Prey and Owls - Journal of Raptor Protection of Slovakia 12: 19-20. [in Slovak]

Макатsсн, W. (1948): Der Schwarze Milan als Wintergast in Griechenland. - Ornithologische Berichte 1: 143-145. 
Mills, S. (2011): Birdwatching in Northern Greece. A site quide. - BirdWING Books, 158 pp.

Nachtigall, W., Stubbe, M., Herrmann, S. (2003): Aktionsraum und Habitatnutzung des Rotmilans (Milvus milvus) im Winter - eine telemetrische Studie im Nordharzvorland. - Journal of Ornithology 144: 284-294. https://doi.org/10.1007/BF02465628

Ortuieb, R. (1998): Der Schwarzmilan. Die Neue Brehm-Bücherei Bd. 100. - Westarp Wissenschaften, Hohenswarsleben, 176 pp.

Patev, P. (1950): Pticite v Balgarija [Birds of Bulgaria]. - BAN Publishing, Sofia, 364 pp. [in Bulgarian]

Pfeiffer, T. \& Meyburg, B. U. (2009): Satellitentelemetrische Untersuchungen zum Zugund Überwinterungsverhalten thüringischer Rotmilane Milvus milvus. - Vogelwarte 47: 171-187.

Pütz, K., Helbig, A. J., Pedersen, K. T., Rahbek, K. T., Saurola, P. \& Juvaste, R. (2008): From fledging to breeding: long-term satellite tracking of the migratory behaviour of a Lesser Black-backed Gull Larus fuscus intermedius. - Ringing and Migration 24: 7-10. https://doi.org/10.1080/03078698.2008.9674376

RaAb, R., Literák, I., Schütz, C., Spakovszky, P., Steindl, J., Schönemann, N., Tarjányi, S. G., Peške, L., Makoñ, K., Mráz, J., Maderič, B., PečeňÁ́, V., Matušík, H. \& Schulze, C. H. (2017): GPS-basierte Telemetriestudien an mitteleuropäischen Rotmilanen Milvus milvus - methodische Schwierigkeiten und analytische Möglichkeiten basierend auf ersten Ergebnissen. - Ornitologische Mitteilungen 69: 245-260.

RAK, D. (2013): Luňák červený (Milvus milvus) [Red Kite (Milvus milvus)]. - Zpravodaj Skupiny na ochranu a výzkum dravců a sov 13: 36-38. [in Czech]

SARÀ, M. (2003): The colonization of Sicily by the Black Kite (Milvus migrans). - Journal of Raptor Research 37: 167-172.

Schröpfer, L. (2008): Luňák červený Milvus milvus Haja červená Red Kite. Pp. 278-279. In: Сери́к et al. (eds): Atlas migrace ptáků České a Slovenské republiky [Czech and Slovak Bird Migration Atlas]. - Aventinum, Praha. [in Czech, with an English summary]

Shirihai, H., Yosef, R., Alon, D., Kirwan, G. M. \& SpaAr, R. (2000): Raptor migration in Israel and the Middle East. - International Birdwatching Centre Eilat, IBRCE, IOC, SPNI, Eilat, 192 pp.

Simeonov, S. D., Michev, T. M. \& Nankinov, D. N. (1990): Fauna na Balgarija (Fauna of Bulgaria 20, Aves Vol. 1). - BAN Publishing, Sofia, 350 pp. [in Bulgarian]

Stoynov, E., Peshev, H. \& Grozdanov, A. (2014): Rare birds of prey observations in Kresna Gorge in Bulgaria. - Vulture News 66: 56-59.

ŠŤAstný, K., BejČeK, V. \& Hudec, K. (2006): Atlas hnízdního rozšírení ptáků v České republice 2001-2003 [Atlas of Breeding Birds in the Czech Republic 2001-2003]. - Aventinum, Praha, 464 pp. [in Czech, with an English summary]

VAlet, G. (1975): La sedentarisation du Milan royal Milvus milvus en Auxois. - Alauda 43: 263-269.

WeIr, D. N. (1973): Winter range of a Red Kite in East Inverness-shire. - Scottish Birds 7: 257-258.

Vidal-Mateo, J., De La Puente, J., Mellone, U., Bermejo, A. \& Urios, V. (2015): Migration routes and wintering areas of wintering Red Kites in Spain. P. 25. In: De La Puente, J., \& De La Torre, V. (eds): Abstracts Book of the II International Symposium on the Red Kite. - Edit Grupo Ornitológico SEO-Monticola and Fondo de Amigos del Buitre, Binaced.

Zuna-Kratky, T., Kalivodová, E., Kürthy, A., Horal, D. \& Horák, P. (2000): Die Vögel der March-Thaya-Auen. - Distelverein, Deutsch Wagram, 285 pp.

Received February 22, 2019, accepted August 25, 2019, published November 22, 2019 